\title{
Rationality and Society
}

http://rss.sagepub.com

\section{Power, Trust, and Institutional Constraints: Individual Level Evidence}

Sven Oskarsson, Torsten Svensson and PerOla Öberg

Rationality and Society 2009; 21; 171

DOI: $10.1177 / 1043463109103898$

The online version of this article can be found at:

http://rss.sagepub.com/cgi/content/abstract/21/2/171

\author{
Published by: \\ (9)SAGE \\ http://www.sagepublications.com
}

Additional services and information for Rationality and Society can be found at:

Email Alerts: http://rss.sagepub.com/cgi/alerts

Subscriptions: http://rss.sagepub.com/subscriptions

Reprints: http://www.sagepub.com/journalsReprints.nav

Permissions: http://www.sagepub.co.uk/journalsPermissions.nav

Citations http://rss.sagepub.com/cgi/content/refs/21/2/171 


\title{
POWER, TRUST, AND \\ INSTITUTIONAL CONSTRAINTS
}

\author{
INDIVIDUAL LEVEL EVIDENCE
}

\author{
Sven Oskarsson, Torsten Svensson, and PerOla Öberg
}

\begin{abstract}
This article focuses on how institutions matter in generating relationships of trust in an environment of unequal power. Trust is seen as the truster's expectation that the trustee will act trustworthily out of moral commitment and/or interest in continuing the relationship. Using crosssectional data from a survey conducted in 2006 on Swedish employment relations the authors show that perceived power asymmetries between an employee and his or her superior have a negative impact on trust. However, perceptions about the enforcement and fairness of institutional constraints - rules for dismissal, conflict resolution, wage setting, and promotion - have conditioning effects. When the respondents perceive the rules as fair, trust is less influenced by increasing power asymmetries between an employee and his or her superior. The results have important implications. By designing institutions that are considered fair, distrust may be mitigated even in situations characterized by extensive power asymmetries.
\end{abstract}

KEYWORDS $\bullet$ employment relations $\bullet$ institutions $\bullet$ power $\bullet$ trust

A large body of research has shown that high levels of trust have wide-ranging positive societal effects: when citizens trust each other, democratic stability is promoted, society is more inclusive and open, economic development is furthered, and feelings of well-being flourish (Zak and Knack 2001; Uslaner 2002). However, less is known about the origins of trusting relationships. Existing research on the roots of trust shows that impartial, uncorrupted and equality-enhancing institutions seem to matter in generating relationships of trust (Delhey and Newton 2003; Rothstein and Uslaner 2005). An important question here is: How do the causal mechanisms assumed to underpin these relationships actually work?

Rationality and Society Copyright (C) 2009 Sage Publications. Los Angeles, London, New Delhi, Singapore and Washington DC, Vol 21(2): 171-195.

http://rss.sagepub.com DOI: 10.1177/1043463109103898 
We believe that an impediment to unfolding these mechanisms is the theoretical vagueness of the trust concept in much of the earlier empirical research on the antecedents of trust. Consequently, this paper departs from a discussion of how we should understand trust. We define trust as a relational concept in which trust is seen as the truster's expectation that the trustee will act trustworthily out of moral commitment and/or interest in continuing the relationship. Hence, we argue against the bulk of scholars studying trust who assume that trust is based either on an assessment of others' moral commitments or interests in continuing the relationship.

Three main implications follow from this understanding of trust. First, we expect power asymmetries to influence trust between individuals negatively. Second, the degree of trust in a relationship should be affected by perceptions about the formal constraints governing the relationship. Above all, expectations of duly enforced and fair institutional constraints will further relations of trust. Third, fair institutional constraints will mitigate the impact of power asymmetries and perceptions about the enforcement of institutions on trust.

We test these hypotheses using cross-sectional data from a Swedish survey conducted in 2006 directed to employees and posing questions about conditions of and perceptions about their workplaces. By specifying a relevant relationship we are able to test how institutions create trust more accurately than has been done hitherto. The results strongly confirm the theoretical arguments of this study. We find that perceived power asymmetries do have a negative impact on trust between an employee and his or her superior. Furthermore, perceptions about the enforcement and fairness of institutional constraints governing the relationship between employees and employers - such as rules for dismissals, conflict resolution, wage setting, and promotion - have both direct and conditioning effects on trust. First, employees' trust in their superiors is positively related to the degree to which they perceive the institutional constraints as efficiently implemented and fair. Second, the results show that when the respondents perceive the rules for conflict resolution, wage setting, and promotion as fair their trust in their superiors is less influenced by power asymmetries and perceptions about the enforcement of institutions. This has important implications for policies in situations where trust is believed to be crucial. By designing institutions that are considered fair, distrust may be mitigated even in situations characterized by extensive power asymmetries.

\section{Trust, Power, and Institutional Constraints - Five Hypotheses}

Following Uslaner (2002) we should make a clear distinction between two different kinds of trust. According to the first concept, some people have 
a disposition to trust (Rotter 1971; 1980; Uslaner 2002). The disposition to trust is a default expectation of other individuals' goodwill. Thus, it is a character trait, which leads people to believe that the world is a benevolent place and other people have benign intent (Rosenberg 1956; Miller and Mitamura 2003). As such, it is not based upon ongoing personal relationships and remains more or less stable no matter what the individual experiences. People are either born this way or learn to be more or less trusting as a result of experiences during their early childhood.

The possible disposition to trust has nothing to do with assessments of the trustworthiness of others. Such inquiries into the trustworthiness of those trusted is instead at the heart of the second concept of trust - the relational view of trust (Hardin 2002; Uslaner 2002; Cook et al. 2005). According to this account, trust is seen first and foremost as a property of a social relation between two or more individuals or actors (Hardin 1993; 1998; Yamagishi and Yamagishi 1994; Ullmann-Margalit 2004). Trust results from information about and past experience with the trustee and the situation at hand and is a prediction about another person's behavior. My trust in you hinges on my belief that you will act in accordance with my interests.

It is important to note here that these two views of trust - trust as a disposition and the relational view of trust - are not contradictory. This becomes evident when looking at one's trust in a specific individual or actor. Even if placing great faith in people in general we should still expect someone who is disposed to high trust to ponder on a specific trustee's capacity and motivation for being trustworthy. Thus, in specific trust relationships such as those between employers and employees, doctors and patients, or buyers and sellers - we can treat the truster's possible disposition to trust as a baseline. The dispositional truster will more frequently develop relationships of trust with new people. But in the end such relationships are determined by one's assessment of the potential trustee's trustworthiness irrespective of one's disposition to trust. In the empirical part of the article we will follow this line of thought by controlling for trust as a predisposition while using a measure of a specific trust relationship between an employee and his or her nearest superior as the outcome variable.

Consequently, the focus of this study is on the relational element of trust in specific actors. Our understanding of trust is based on, but also extends, the model of trust associated with Russell Hardin and his colleagues (Hardin 2002). An actor A is said to trust another actor B 'when A believes that B is trustworthy with respect to the matters at hand' (Cook et al. 2005: 20). In this sense, A's trust in B depends on A's assessment of B's intentions towards A. The main question here is on what grounds A makes this assessment of B's intentions? Two contrasting approaches can be found in the relevant literature. First of all, trust can be understood as encapsulated interest 
(Levi 1998; Hardin 2002; Cook et al. 2005). Hence, I trust you since I believe that you encapsulate my interests in your own and that you value the continuation of our relationship. According to the second approach, trust does not depend on the truster's expectations about the trustee's interests. Instead, trust hinges on beliefs about the moral commitments of the potentially trusted individual or actor (Williamson 1993; Becker 1996; Tyler 1998; DiMaggio 1999). Thus, I trust you, irrespective of my beliefs about your specific interests; since I believe that you are morally committed to act trustworthily towards me (in this specific matter).

We believe that this sharp dividing line between trust as encapsulated interest and trust based on moral commitments should be avoided. There is no apparent reason why we should assume that people's trust rests on either assessments about others' interests or moral commitments alone. Instead, we argue that people can be trustworthy for both of the above reasons. Therefore, we say that someone is trustworthy if he or she encapsulates our interests and/or is morally committed to doing so.

The assumption underlying this argument is that most people do not act on the basis of a single rational utility maximizing utility function. Instead individuals weight their self-interest against their commitment to adhere to moral values in a dual utility function (Levi 1991; Rothstein 2001). The weight given to self-interest and moral commitment, respectively, might differ across individuals and situations. However, it seems far-fetched to believe that more than a minuscule part of mankind act solely on the basis of moral commitment or self-interest across every conceivable situation and towards every conceivable other person. Consequently, since we believe that an individual's actions can be motivated by both self-interest and moral commitment, it is not a great step to also argue that an actor's expectation of someone else's trustworthiness can rest on an assessment of both his or her self-interest and moral commitment.

Three general conclusions concerning the causal nexus explaining trust follow from this definition. First of all, A's trust in B is an increasing function of A's expectation that B encapsulates his or her interests. Second, A's trust in B will increase to the extent that A believes that B is motivated by a moral commitment to act trustworthily. Third, the higher A's expectations that B is morally committed to act trustworthily, the less A's trust will be influenced by his or her expectations about B's interests. Or, put differently, if I am convinced that a person acts on the basis of a moral commitment to be trustworthy the question of coincident interests is of less importance for my trust in the other person. These three implications are illustrated in Figure 1.

The positive slopes of the lines indicate that my trust in a person increases to the degree I expect his or her interests to coincide with 


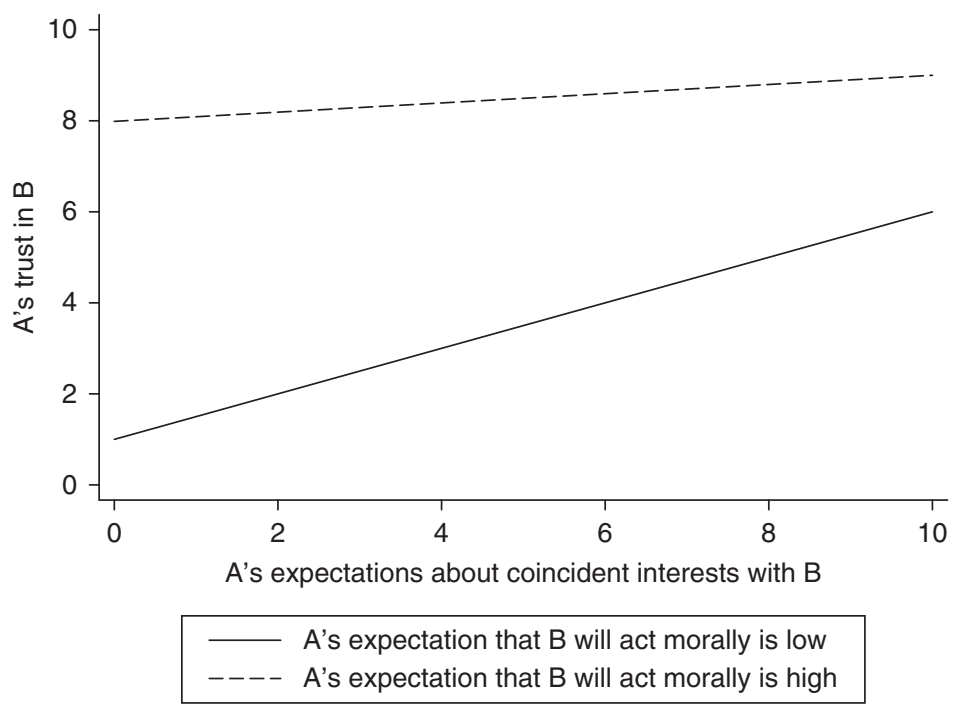

Figure 1. A model of individual A's trust in individual/actor B.

mine. Furthermore, the fact that the dashed line is positioned over the continuous line mirrors the expectation that my trust in a person will increase to the extent that I believe that he or she is motivated by a moral commitment to act trustworthily. Finally, the flatter slope of the dashed line corresponds to the argument that my trust in a person is less affected by changes in what I believe to be his or her interests if I expect him or her anyway to act on the basis of moral commitments.

The question then turns into the following: Which factors should we expect to influence the truster's assessment of the trustee's interest in acting and moral commitment to act trustworthily? Having defined trust as a property of a social relation, other aspects of this relationship naturally come into focus. Above all, we agree here with Cook et al. (2005: 40) and Öberg and Svensson (2009) that there is good reason to focus more on the relation between trust and power than hitherto has been done in research on trust:

Power inequalities are ubiquitous in modern societies; thus, any treatise on trust must take them seriously. They cannot be assumed away in any theory that deals with the world of social relations and social institutions.

Following Farrell (2004; see also Knight 1992; Coleman 1994; Hardin 2004) we treat power as a relational construct and define it as the level of cost incurred if one unilaterally withdraws from a relationship: a low cost of withdrawal implies high power; a high cost implies low power. So if 
I find that another actor is much more powerful than me, I would, by implication, also suspect that he or she has less interest in my resources and could easily withdraw from our relationship.

Thus, the more powerful someone is in a specific relationship, the easier it is to withdraw from this relationship. Given this and the definition of trust discussed above, the first hypothesis about the relationship between power and trust to be tested in this study follows straightforwardly:

H1: the more power individual or actor B has over individual A, the less A trusts B.

Thus, power inequalities first and foremost affect one's assessment of the trustee's interests in acting trustworthily. When the power of B relative to A increases it will be less expensive for B to break the relationship with A. Consequently, A will be less likely to believe that B encapsulates his or her interests and is willing to act trustworthily. Hence, the general idea in the referred literature is that power asymmetries negatively influence trust or at least that 'power impedes the development of trust' (Cook et al. 2005: 42). In one vigorous formulation, power may actually 'drive out trust' (Farrell 2004: 85).

However, to say that power drives out trust tout court does not seem very reasonable. If anything, this would entail very low levels of trust continuously across both time and space since power inequalities are inevitable in societies as we know them. A stable and effective society not only allows citizens to feel secure on the streets and in the shops but also provides a context for individuals to begin to take risks with each other. In other words, a functioning society needs a proper institutional framework to enable individuals to trust each other and to embark on cooperative ventures in spite of power asymmetries (North 1990; Ostrom 1990; 2000; Cook et al. 2005: 159-165; Öberg and Svensson 2009).

But what is a proper institutional framework and how do institutional constraints influence trust? In this paper we adhere to North's conception that institutions 'are the rules of the game in a society or, more formally, are the humanly devised constraints that shape human interaction' (North 1990: 3). Given our definition of trust and assumption about dual utility functions, such an institutional framework should affect the truster's assessment of the potential trustee's self-interest and/or moral commitments to enhance trust.

We believe there is reason to expect institutional constraints to affect trust through both these routes. First of all, following Weber we argue that to have an effect on actors' expected utilities from different choices, and, by implication, on individuals' assessments of other actors' expected utilities, a constraint must be effectively enforced: 
To the person who finds himself in possession of power to control an object or a person the legal guaranty gives a specific certainty of the durability of such power. To the person to whom something has been promised the legal guaranty gives a higher degree of certainty that the promise will be kept. These are indeed the most elementary relationships between law and economic life.

(Weber [1922] 1968: 730)

That institutional constraints can influence behavior by affecting the expected utility from different choices of behavior is, of course, well established in the rational choice oriented literature in political science (e.g. Hall 1986; Elster 1989; Shepsle 1989) and economics (North 1990), but also - although with some slightly different meanings - in related research on economic action and new institutionalism (Granovetter 1985; Koelble 1995; Swedberg 2003). We argue that the same constraints should also affect how we assess other individuals' trustworthiness. More precisely, properly enforced institutional constraints stipulating rights and duties in the relationship between individuals/actors will make it more expensive for individual or actor B to break the relationship with individual A. Thus, A will be more likely to believe that B encapsulates his or her interests and therefore is willing to act trustworthily. In line with this the second hypothesis states:

H2: the extent to which an individual A perceives the institutional constraints governing the relationship with individual or actor B as duly enforced will increase his or her trust in the opposite party.

Second, the mere existence of constraints is not the only way institutions can create an environment that is conducive to enhanced levels of trust. Just as important is the quality or performance of institutions rather than their descriptive characteristics or attributes. We argue here that the degree to which the formal constraints governing the relationship are perceived as fair and just by the individuals will enable increased levels of trust. The underlying logic is well captured in Rawls' A Theory of Justice:

given that a person's capacity for fellow feeling has been realized [according to the
first law], and given that a social arrangement is just and publicly known by all to be
just, then this person develops ties of friendly feeling and trust towards others in the
association as they with evident intention comply with their duties and obligations,
and live up to the ideals of their station.

(Rawls 1971: 490)

Thus, we should expect the perceived procedural fairness of institutions to influence individuals' propensity to act on the basis of moral commitments (Ostrom 1990; Rawls 1999; Levi et al. 2004). Consequently, given that A perceives the institutional constraints as fair, his or her expectation that $\mathrm{B}$ will decide to act trustworthily on the basis of moral convictions will rise. 
Recent research on the interrelationship between welfare institutions, political confidence, and social trust renders some support for this last line of thought. Especially, it has been shown that citizens who perceive welfare institutions as fair and just are more supportive of the political regime and its institutions (Kumlin 2004) and more trusting towards their fellow citizens (Rothstein and Stolle 2003; Rothstein 2004; Kumlin and Rothstein 2005). Such feedback mechanisms going from formal institutions to trust might very well be valid in circumstances other than the vertical trust relationship between a citizen and the political authorities and the horizontal trust relationship between citizens.

Consequently, we should expect the degree of trust in any relationship to be affected by the formal constraints governing the relationship. Thus, there is reason to state a more general hypothesis about the relationship between the perceived fairness of institutional constraints and trust and test whether:

H3: the extent to which an individual A perceives the institutional constraints governing the relationship with individual or actor B as fair will increase his or her trust in B.

It is important to note here that the three hypotheses outlined above hinge on our definition of trust as an actor's expectation of someone else's trustworthiness based on an assessment of both his or her self-interest and moral commitment. If trust rests solely on one's beliefs that the trustee is morally committed to act trustworthily the first two hypotheses would be inconsistent since they concern the interest side of the trust equation. Following Yamagishi and Yamagishi (1994) we would instead expect that, for example, strong institutional constraints and other forms of assurance (H2) actually decrease trust. If, on the other hand, we would follow Hardin (2002) and assume that trust equals encapsulated interest there would be no grounds for expecting that perceptions about the fairness of the institutional constraints should affect an individual's trust (H3) since there is no immediate reason to expect that perceptions of fairness should affect an individual's assessment of someone's self-interest. For the third hypothesis to be valid we have to assume that trust is also driven by moral commitment.

Finally, by combining the arguments underpinning the first three hypotheses we can state two more conditional hypotheses about the relationship between power, institutional constraints, and trust. The starting point here is the logic behind the third hypothesis which says that institutional constraints that are perceived as procedurally fair change how individuals assess others' expected behavior. Thus, given that a person A perceives the institutional constraints as fair, his or her expectation that individual $\mathrm{B}$ will decide whether to act trustworthily or not on the basis of moral convictions will rise and, consequently, A will consider it less likely that B will act out of self-interest. 
But, saying that less weight is given to the self-interest side of the trust equation is tantamount to saying that changes in one's assessment of the other's interest in acting trustworthily are less important when deciding whether to trust someone or not. Or, put differently, if institutional fairness has led me to the belief that a person acts on the basis of a moral commitment to be trustworthy, the question of coincident interests is of less importance for my trust in the other person. Consequently, since power inequalities (H1) and perceptions that the institutional framework is duly enforced (H2) first and foremost affect one's assessment of coincident interests we should expect these factors to be less influential when a person perceives the institutional framework as fair. Operationally, this argument leads to two more hypotheses:

H4: the extent to which individual A perceives the institutional constraints governing the relationship with individual or actor B as fair will decrease the impact of power on trust.

H5: the extent to which individual A perceives the institutional constraints governing the relationship with individual or actor B as fair will decrease the impact of A's perceptions that the institutional framework is duly enforced by his or her trust in B. ${ }^{1}$

\section{Data and Operationalizations}

In order to empirically test the five hypotheses, we have, first of all, to pinpoint a situation where relations of trust and power are important. Furthermore, this relationship should preferably be embedded in easily recognizable institutional constraints. There are, of course, several possible situations to study. We argue that the employment relation between employer and employee nicely fits the above-mentioned criteria.

First, successful exchange and transactions between employers and employees are essential to economic growth. Not only is it important that agreements are settled; they have to be settled without too large costs arising from complicated contracts and supervising. Thus, trust is an essential ingredient in making the employment relation work efficiently. However, due to uncertainties about the other's behavior and motivations, both parties have incentives to secure themselves from being exploited or deceived, and may be tempted to engage in complicated (and costly) contracts (Ouichi 1980). Furthermore, the relationship between employers and employees is highly asymmetrical owing to the inherent problem of adding units of labor power whereas units of capital easily can merge. These uncertainties and power asymmetries will render the development of feelings of trust much harder (Offe and Wiesenthal 1980; Oskarsson 2002). 
Second, laws and other institutions regulate employment relations in all countries, and specify for example industrial management rights, wage setting, job security, and rules for conflict resolution (Botero et al. 2004). Thus, labor market institutions and laws regulate property rights for both employers and employees. Since these institutions do not regulate every part of an employment relationship, employers and employees are constantly involved in exchange situations where relations of trust and power are also important (Svensson and Öberg 2005).

At the aggregate level, such institutional constraints have been shown to influence a wide range of essential labor market outcomes such as growth (Eichengreen and Iversen 1999), unemployment (Iversen 1998), inflation (Crepaz 1992), wage inequality (Golden and Londregan 2006), unionization (Oskarsson 2003), and strike levels (Hibbs 1976). Here we instead turn to the microlevel to investigate whether perceptions about institutional constraints at the workplace level affect employees' trust in their superiors. In order to study these effects we rely on an extensive survey of Swedish workplace relations. The Swedish case is a highly suitable testing ground for the five hypotheses outlined above. Most importantly, labor laws in Sweden are extensive and universal. Most employees in Sweden have equivalent job security and are affected by one distinct system of conflict resolution when involved in individual disputes.

The survey was conducted in cooperation with Statistics Sweden in late spring $2006 .^{2}$ A random sample of 3000 respondents was selected based on a register of all Swedish citizens between 20 and 65 years of age: 1551 individuals answered the postal questionnaire after three reminders, i.e. a response rate of 52 percent. The analyses in this article are based on answers from the slightly more than 900 respondents that indicated that they had been working mainly as employees in the last month. Before we proceed to the analysis, we will explain how our basic concepts are measured. ${ }^{3}$

\section{Power}

As opposed to studies where power is treated as a resource or an attribute of an actor (e.g. Korpi 1985), we have defined power as a relational construct (cf. Knoke 1990; Coleman 1994: 43). We use two different measures to tap the power asymmetries in the relationship between an employer and an employee. First of all, we have employed a straightforward question about the respondent's possibilities to influence conditions at his or her workplace if it entails persuading the nearest superior (Power 1). ${ }^{4}$ This item is clearly a relational measure of 
power in that it is dependent on the relationship in which it is exercised. However, an obvious objection against this measure is that it is not exogenously related to trust. Thus, there is good reason to suspect that employees who believe they can persuade their superiors do so because they trust their superiors. Therefore we have also used a slightly different measure intended to tap the extent to which the respondent perceives the resources he or she brings into the relationship are valuable to the employer (Power 2). ${ }^{5}$

\section{Perceptions of Institutions}

Formal institutional frameworks that act as impartial third parties with enforcement capacity are essential to reduce uncertainty about the behavior of others. Hence, a first condition in order to have an effect on feelings of trust in specific relations is that there exist institutions that regulate the property rights of the involved parties. As we have argued above, labor law may have such a function.

Indeed, there are a number of institutions that regulate employment relations in modern capitalist countries. We have focused on institutions in four crucial areas of working life that cover the most essential components of employment relations: decisions about promotion, wage setting, local conflict resolution, and job security. In Sweden, these areas are regulated in law as well as in collective agreements. Roughly, the regulations become more detailed on a sliding scale from regulations about promotions to rules about job security.

There is no general instruction in public law that requires Swedish employers to treat employees fairly and objectively (Sigeman 2001: 101). But Sweden has several laws (to a large extent coordinated with EU regulations) against discrimination at work. These regulations cover most situations in employment relations, especially wage-setting procedures and decisions about promotion. Thus, it is forbidden by law to discriminate due to gender, ethnic origin, religion, sexual preferences, mental or physical disabilities, trade union membership or part-time working (Meyersson Milgrom et al. 2001; Rydgren 2004).

Conflict resolution is mainly regulated in collective agreements. When a dispute between an employer and employees arises, the first stage for the employees is to approach their workplace trade union representative. If the local parties are unable to resolve the conflict, negotiations will follow between the employer's association and the trade union at national branch level. If they too are unable to come to a resolution of the conflict, the case can be taken to the tripartite Labor Court, where it can be settled 
through continued negotiations or arbitration, or - as a last resort - by a formal decision by the Labor Court.

Job security in Sweden is regulated in special legislation primarily stipulated in the Employment Protection Act (SFS 1982: 80; Holmlund and Storrie 2002). The law presumes that, unless otherwise stipulated, an employment contract is valid until further notice. When terminating the contract, the employer must provide a valid reason - the circumstance appealed to should constitute a 'just cause' for dismissal - and advance notice. Furthermore, the Act states that the order of priority in a redundancy situation shall be determined on the basis of employee seniority. This is often referred to as the 'last in - first out' principle.

In the analysis we will focus on the respondents' perceptions of the rules for dismissals, conflict resolution, wage setting, and promotion. As stated above, we argue that the extent to which the institutional constraints are perceived as fair and/or duly enforced is decisive. Ideally, therefore, we should have separate measures tapping perceived fairness and enforcement of dismissal, conflict resolution, wage setting, and promotion rules, respectively. Unfortunately, this is not the case. Instead we measure the extent to which the respondents perceive that the rules for dismissals are enforced and whether they think that the rules for conflict resolution, wage setting, and promotion are fair. ${ }^{6}$ In the end this means that although we are able to test the effects of perceived fairness and perceived enforcement separately we cannot tell which effect is stronger. ${ }^{7}$

\section{Trust}

As argued in the theory section, we should make a clear distinction between two different kinds of trust - a disposition to trust and the relational view of trust. In specific trust relationships we can treat the truster's possible disposition to trust as a baseline. Thus, in the empirical models of employees' trust in their employers we will include a measure of the respondent's disposition to trust as a control variable. We measure this disposition using the standard survey research question: 'Generally speaking, would you say that most people can be trusted, or that you can't be too careful in dealing with people?' This well-known measure of generalized trust has been widely criticized for a number of reasons (Foley and Edwards 1999; Glaeser et al. 2000). Above all, it has been noted that the wording of this survey item is ambiguous since it does not ask the respondent to choose between trust and distrust. Rather, respondents are prompted to choose between trust and caution (Miller and Mitamura 2003). However, this ambiguity is a problem only insofar as we contrast 
generalized trust to generalized distrust at the conceptual level. As argued above, we should rather understand the opposite of a disposition to trust as a disposition to be cautious. Thus, the idea of a disposition to trust adhered to in this paper is well captured by the standard question on trust (Uslaner 2002). ${ }^{8}$

Finally, in order to capture the relational view on trust we focus on the employee's trust in his or her superior. This is measured in two different ways in this article. First, by a straightforward question in which the respondent in the questionnaire is asked to what extent he or she trusts his or her nearest superior. The second question takes as a starting point the concrete situation after an agreement or contract has been reached, namely the extent to which the employee thinks that his or her superior actually keeps his or her word and does what he or she has promised to do. In the analysis to follow we have combined the two questions into a single additive index on trust. ${ }^{9}$

\section{Results}

The results of the analyses are presented in Table $1 .{ }^{10}$ In order to save some space we present only the estimates of the relevant variables measuring power, perceptions of institutional constraints, and trust. To simplify interpretation of the estimates all variables are recoded in the 0-1 range. Looking first at Model 1, we can see that the first hypothesis is corroborated by the estimates. The measure of power is both substantially and significantly related to trust in one's superior at the workplace. When not taking account of the hypothesized mitigating effect of institutional constraints, it is clear that power does drive out trust. ${ }^{11} \mathrm{~A}$ maximum increase (0-1) in the respondent's perceived possibility to persuade the nearest superior in order to influence matters important to him/her (Power 1) results in 0.37 points increase in the $0-1$ trust scale.

However, as suggested by the second and third hypotheses, it is also evident that perceptions about enforced and fair institutions facilitate relations of trust in spite of enduring power asymmetries. The extent to which the respondents think that rules for conflict resolution, promotion, and wage setting are fair (Fairness index) and regulations regarding dismissals are followed at the workplace are positively related to the expressed trust in their superiors.

A possible objection against these results is the assumed causal order between power and perceptions about the institutional framework, on the one hand, and feelings of trust, on the other. To somewhat alleviate 
this problem we employ a different measure of power (Power 2) in the third model. This indicator taps the degree to which the respondent perceives that the resources he or she brings into the relationship are valuable to the employer. ${ }^{12}$ As expected, the effect of this variable is substantially smaller than the previous one. More important, though, is that we still can conclude that power asymmetries negatively influence trust. An increase (0-1) in the second power measure results in 0.09 points increase in the $0-1$ trust scale.

Turning next to the causal order between perceptions about institutions and attitudes of trust, here we have to rely solely on reasonable arguments. Since we are dealing with cross-sectional data we cannot solve this problem empirically. Although we cannot rule out the possibility that trust is an important precondition for the establishment and maintenance of formal institutional constraints we believe there are stronger arguments for the opposite causal ordering: that the degree of trust in any relationship will be affected by perceptions of the constraints governing the relationship.

This is especially true of respondents' perceptions of enforced institutions. To measure this we asked the respondents to what extent they thought that rules for dismissals were followed in their workplaces. Given the clarity and centrality of this rule for Swedish employment relations it is reasonable to assume that an employee has first-hand knowledge whether the law is conformed to or not at his or her workplace. Thus, already being informed, an employee's trust in the superior should not affect the degree to which he or she thinks the rules for dismissals are obeyed. The opposite scenario, however, is more plausible. The degree to which the rules for dismissals are deviated from at a particular workplace will lead to decreases in the levels of trust between employees and their superiors.

Concerning the relationship between perceptions of fair institutions and trust the argument for the causal order is not as obvious. Above all, it does not seem too far-fetched to think that an employee's trust towards his or her superior could affect perceptions of how rules for promotion, wage setting, and conflict resolution work at the workplace. However, the results in Table 1 confirm findings from a conceptually similar but empirically different field of research stating that citizens who perceive welfare institutions as fair and just are more supportive of the political regime and its institutions (Kumlin 2004) and more trusting towards their fellow citizens (Rothstein 2004; Kumlin and Rothstein 2005). In line with this we argue that there are good reasons to believe that the results of Models 1 and 3 indicate not just a correlation but also a causal effect of the respondents' perceptions of fair rules on their trust towards the superior. 
Table 1. OLS regression models for trust (robust standard errors in parentheses)

\begin{tabular}{|c|c|c|c|c|}
\hline & Model 1 & Model 2 & Model 3 & Model 4 \\
\hline Power 1 & $\begin{array}{l}0.370 * * * \\
(0.034)\end{array}$ & $\begin{array}{l}0.470 * * * \\
(0.074)\end{array}$ & & \\
\hline Power 2 & & & $\begin{array}{l}0.087 * * * \\
(0.027)\end{array}$ & $\begin{array}{l}0.191 * * \\
(0.076)\end{array}$ \\
\hline Enforced procedures & $0.210^{* * *}$ & $0.330 * * *$ & $0.235^{* * *}$ & $0.339 * * *$ \\
\hline (Dismissals) & $(0.030)$ & $(0.071)$ & $(0.033)$ & $(0.072)$ \\
\hline Fair procedures & $0.249 * * *$ & $0.606^{* * *}$ & $0.394 * * *$ & $0.757 * * *$ \\
\hline (Fairness index) & $(0.039)$ & $(0.101)$ & $(0.040)$ & $(0.120)$ \\
\hline Power $1 \times$ & & $-0.209^{*}$ & & \\
\hline Fair procedures & & $(0.126)$ & & \\
\hline Power $2 \times$ & & & & $-0.204^{*}$ \\
\hline Fair procedures & & & & $(0.123)$ \\
\hline Enforced procedures $x$ & & $-0.289 * *$ & & $-0.264^{*}$ \\
\hline Fair procedures & & $(0.131)$ & & $(0.138)$ \\
\hline Generalized trust & $\begin{array}{l}0.084 * * * \\
(0.028)\end{array}$ & $\begin{array}{l}0.081 * * * \\
(0.027)\end{array}$ & $\begin{array}{l}0.103 * * * \\
(0.029)\end{array}$ & $\begin{array}{l}0.102 * * * \\
(0.029)\end{array}$ \\
\hline Adjusted $R^{2}$ & 0.445 & 0.454 & 0.349 & 0.357 \\
\hline$n$ & 922 & 922 & 930 & 930 \\
\hline
\end{tabular}

Significance levels: $*<0.10 ; * *<0.05 ; * * *<0.01$, two-tailed tests

Note: All models are controlled for: income, sector of employment, occupational status, company seniority, employee responsibility, educational level, gender, and age.

The assumed causal order between perceptions about power relations and the institutional framework, on the one hand, and feelings of trust, on the other, is further strengthened by recent empirical research showing that non-perceptual macro measures of power asymmetries, such as income inequality (Alesina and La Ferrara 2002; Uslaner 2002) and fair institutions (Letki 2006), also account for differences in trust across and within countries. These findings suggest that the potential problem with reciprocal causation when using the cross-sectional perceptual data at hand might not be so troublesome after all.

Turning now to the even numbered models the results of the interaction specifications are encouraging for the theoretical argument of the fourth and fifth hypotheses. All four interaction terms are negatively signed indicating that when the respondents conceive the institutional framework as fair their trust in their superiors is less influenced by perceptions about power relations or the degree to which the rules for 
dismissals are enforced. It is clear that given low levels of perceived fairness of rules for conflict resolution, promotion, and wage setting, the impact of power/perceived enforcement on trust (Models 2 and 4) is substantially larger in magnitude compared to the average effects of Models 1 and 3. When adding the estimates of the interaction terms in Models 2 and 4 we can see that power/perceived enforcement has a distinctly smaller effect on trust when the respondents perceive the institutional framework as functioning fairly.

To get a better sense of the magnitude of the mitigating effect of the institutional constraints, Figure 2 plots the conditional marginal effects and confidence intervals of power and perceptions about rules for dismissals on trust (Models 2 and 4). Once again we see that the pattern of interaction effects is evident. Starting with the effect of the first measure of power (Power 1) on trust in one's superior, in the upper left graph we can see that power has a strong and significant effect on trust when the institutional procedures are perceived as fair. A one unit increase in power is then estimated to increase trust by $0.470 * * *$ units. At higher levels of perceived fairness the marginal effect of power decreases substantially, where a similar one unit increase results in a mere $0.261^{* * *}$ increase in trust. As can be seen from the upper right graph the estimates of the second measure of power (Power 2) reveal a similar pattern. We can see that the marginal effect of power drops from $0.191^{* *}$ to -0.013 when comparing situations of low and high levels of perceived fairness of rules for conflict resolution, promotion, and wage setting.

Turning to the two lower graphs, the same pattern of conditional effects is evident. The marginal effect of perceptions about the degree to which the rules for dismissals are enforced is substantial at lower levels of perceived fairness. When increasing perceived enforcement by one unit, trust in one's superior is estimated to increase by a considerable amount: $0.330 * * *$ units $(0.339 * * *$ units according to Model 4$)$. The marginal effect then turns insignificant at lower levels of perceived fairness: 0.041 (0.075 according to Model 4).

Finally, we can note that, not surprisingly, generalized trust positively affects the specific trust relationship in focus in this paper. However, although the estimates are consistently significant the influence of generalized trust is not overwhelmingly strong. A change in attitudes from holding that 'you can't be too careful in dealing with people' (0) to saying 'that most people can be trusted' (1) is estimated to raise one's level of trust in the nearest superior by roughly 0.1 points. Thus, large increases in generalized trust do not automatically transform into equally large increases in trust towards specific others. This particular result squares well with the 

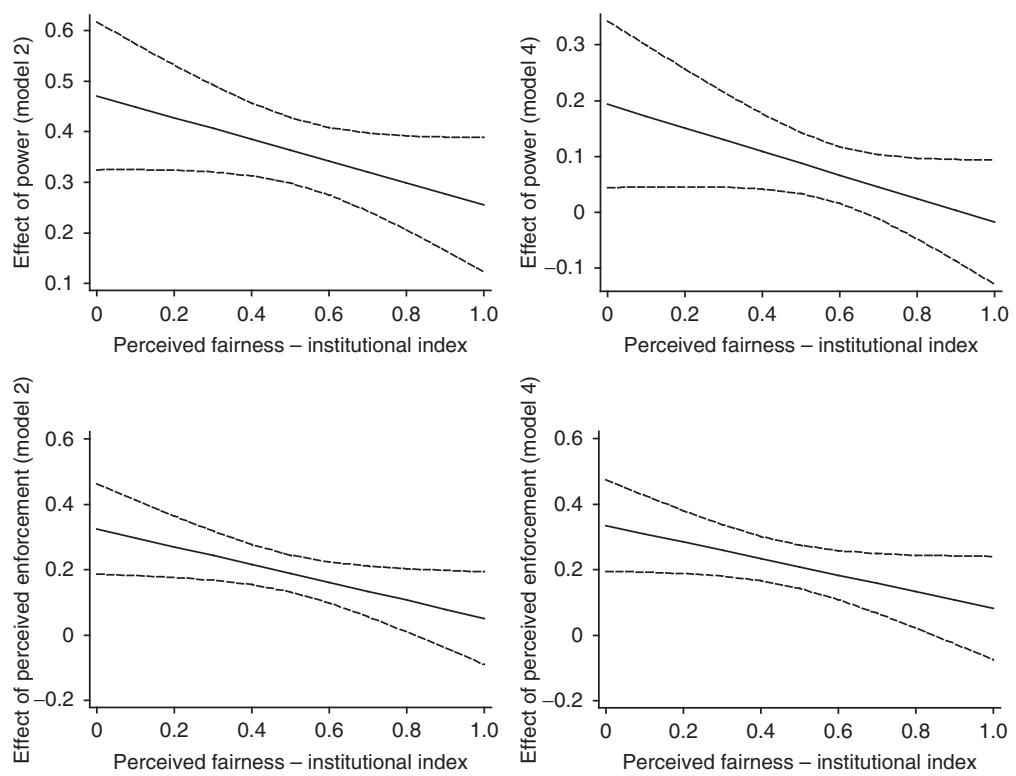

Figure 2 Conditional marginal effects of power and perceived enforcement of institutions on trust with $95 \%$ confidence intervals

distinction made above between a disposition to trust and trust as a relation between actual individuals. The employee's disposition to trust, here measured as generalized trust, may make trusting attitudes towards the superior more likely but far from certain. ${ }^{13}$

\section{Conclusion}

This paper's point of departure was an understanding of trust as a relational concept. We defined trust as the truster's expectation that the trustee will act trustworthily out of moral commitment and/or interest in continuing the relationship. In this way our definition of trust differs from both the conception of trust as a disposition or character trait and the more narrowly based relational views of trust as depending on either encapsulated interests or moral commitments.

Five hypotheses followed from this understanding of trust. First, in accordance with earlier research we expected that power drives out trust: the more power an individual or actor B has over individual A, the less A 
trusts B. The second and third hypotheses stated that the degree of trust in a relationship should be affected by the formal constraints governing the relationship such that the extent to which an individual A perceives the formal constraints governing the relationship with individual or actor $\mathrm{B}$ as fair or duly enforced will increase his or her trust in the opposite party. By combining the theoretical underpinnings of the first three hypotheses we arrived at a fourth and fifth hypothesis saying that the effects of power and perceptions about the enforcement of institutional constraints, respectively, on trust will be mitigated to the extent that an individual A perceives the formal constraints governing the relationship with individual or actor B as fair.

Overall, the empirical analyses confirmed the hypotheses. Using data from a survey on Swedish employment relations we found that perceived power asymmetries between an employee and his or her superior do have a negative impact on trust when not taking the hypothesized conditioning effects of institutional constraints into account. Furthermore, perceptions about the enforcement and fairness of institutional constraints - rules for dismissals, conflict resolution, wage setting, and promotion - proved important in two distinct aspects. First, confirming the second and third hypotheses, we saw that the degree to which the employees perceived the institutional constraints as enforced and fair was positively related to the expressed trust in their superiors. Second, the fourth and fifth hypotheses were also corroborated. The results indicated that when the respondents perceived the rules for conflict resolution, wage setting, and promotion as fair their trust in their superiors was less influenced by changes in power relations and the extent to which they perceived the rules for dismissals as effectively enforced.

Of course these results are open to discussion. As is always the case for research on cross-sectional surveys, the study is flawed with some measurement problems, and interpretations are not totally unambiguous. In order to properly test the relative importance of the perceptions of fair versus enforced institutions we should ideally have included two separate measures in the empirical models. Furthermore, to empirically solve the problem of causal order between attitudinal constructs we need an experimental research design or, at least, panel data. Lastly, in this article, we use data from Sweden only and cross-country comparisons would provide a useful test of robustness.

Nevertheless, we believe there are important lessons to be learnt from this study. Above all, to conclude that institutions matter (for trust as well as most other conceivable human attitudes or behavior) has lately become common enough to turn into a truism. We suggest instead that 
the real importance of institutional constraints lies not so much in their direct effects but in their conditioning influence on other predictors of trust (or, once again, most other conceivable human attitudes or behavior).

If one's trust in another individual or actor was motivated solely by one's assessment about the possible trustee's interests in acting trustworthily, as suggested by the encapsulated interest approach, relations of trust would be fragile indeed and easily develop or break down in response to sudden changes in relative power or regulated costs of breaking the relationship.

If, on the other hand, we stick to the argument that a person's trust stems from his or her assessment about the possible trustee's moral commitment to act trustworthily, it is hard to see why trust relationships should be affected at all by power asymmetries or sanctioning rules.

However, by making the more reasonable assumption that trust can be motivated by one's assessment about the possible trustee's moral commitment to act or interest in acting trustworthily we can get a fuller understanding of both the development and, sometimes, resilience of trusting relationships. Thus, when relationships are embedded in institutional frameworks considered fair and just, individuals will not only be more trusting towards each other. Under these circumstances relations of trust will also be more enduring and insulated from short-run changes in the individual's interests in acting trustworthily.

As for policy implications, the conclusion follows directly. The degree of trust is not given: relevant institutions can both create it and insulate it from the potentially undermining impact of power asymmetries. The crux is to pinpoint which institutional constraints are relevant in different situations of human interaction, and, in different social and institutional contexts. A successful institutional reform in one particular context may produce harmful effects in a different setting of institutions and norms. This general problem is, of course, worthy of considerable future research efforts.

\section{Acknowledgments}

Work on this article has been facilitated by generous comments from participants at the Department of Government seminar on Political Economy and Welfare State Politics, Uppsala University. We also want to thank two anonymous reviewers for their helpful comments. Financial support by the National Institute for Working Life (ALI) and the Swedish Council for Working Life and Social Research (FAS) is also gratefully acknowledged. 
Table A1. Descriptive statistics

\begin{tabular}{|c|c|c|c|c|}
\hline & Mean & $\begin{array}{l}\text { Standard } \\
\text { deviation }\end{array}$ & Minimum & Maximum \\
\hline Trust in superior & 0.70 & 0.25 & 0 & 1 \\
\hline Power 1 & 0.59 & 0.26 & 0 & 1 \\
\hline Power 2 & 0.72 & 0.26 & 0 & 1 \\
\hline Enforced procedures & 0.76 & 0.28 & 0 & 1 \\
\hline Fair procedures & 0.54 & 0.23 & 0 & 1 \\
\hline Generalized trust & 0.58 & 0.26 & 0 & 1 \\
\hline \multicolumn{5}{|l|}{ Occupational status } \\
\hline Managers & 0.07 & & & \\
\hline Professional workers & 0.22 & & & \\
\hline $\begin{array}{l}\text { Qualified vocational } \\
\text { training }\end{array}$ & 0.25 & & & \\
\hline Clerical workers & 0.20 & & & \\
\hline Manufacturing workers & 0.27 & & & \\
\hline \multicolumn{5}{|l|}{ Sector of employment } \\
\hline Private sector & 0.43 & & & \\
\hline Public sector & 0.52 & & & \\
\hline Other sector & 0.05 & & & \\
\hline \multicolumn{5}{|l|}{ Educational level } \\
\hline $\begin{array}{l}\text { Primary and lower } \\
\text { secondary }\end{array}$ & 0.18 & & & \\
\hline Secondary (practical) & 0.18 & & & \\
\hline Secondary (theoretical) & 0.20 & & & \\
\hline First stage of tertiary & 0.13 & & & \\
\hline Second stage of tertiary & 0.30 & & & \\
\hline \multicolumn{5}{|l|}{ Other control variables } \\
\hline Company seniority & 9.83 & 9.993 & 0 & 47 \\
\hline Responsibility & 0.23 & & & \\
\hline Income & 270000 & 219000 & 0 & 4019000 \\
\hline Age & 44.76 & 12.00 & 20 & 65 \\
\hline Gender & 0.52 & & & \\
\hline
\end{tabular}

Note: Operationalizations for the first six variables are presented in the text. Occupational status, sector of employment, and educational level are dummy variables. The share in each category is presented in the table. Company seniority is measured in years of employment at the present workplace. Responsibility refers to the share of employees having responsibility for supervising the work of other employees. Income is measured in Swedish crowns. The gender variable is coded as $0=$ male, $1=$ female .

\section{NOTES}

1. Thus, the relationship between the five empirical hypotheses and the three model implications illustrated in Figure 1 is as follows: Implication 1 corresponds to hypotheses 1 and 2; implication 2 corresponds to hypothesis 3 ; and implication 3 corresponds to the last two hypotheses (4 and 5). 
2. The survey - Work, Trust, and Power in Sweden - will shortly be available to the public from the Swedish Social Science Dataservice.

3. Descriptive statistics for all variables employed in the analysis are presented in the appendix.

4. The question reads: 'How great is your possibility to influence conditions at your workplace if it entails persuading your nearest superior?' The response alternatives run from 0 ('Very little possibility') to 10 ('Very great possibility').

5. The measure is an additive index composed of the following two items: 'The risk of me losing my job is very small.'; 'Even if I work hard, my job is insecure.' The response alternatives run from 0 ('Totally disagree') to 10 ('Totally agree'). The last item is inverted before adding them together.

6. The four items read: 'To what extent do you think that layoff rules are strictly observed at your workplace?'; 'To what extent do you think that disagreements between employers and employees at your workplace are solved in a fair way?'; 'To what extent do you think that wage rates are set fairly at your work place?'; 'In your opinion, how important is an employee's job performance for being promoted at your workplace?' For the first three items the response alternatives run from 0 ('To no extent at all') to 10 ('Completely'). For the last item the response alternatives run from 0 ('Totally unimportant') to 10 ('Very important').

7. In the analyses we have combined the three items tapping the respondent's attitudes on the rules for conflict resolution, wage setting, and promotion into a single additive index on perceived fairness of institutions.

8. This is also more in line with the interpretation of the item that Rosenberg (1956) originally had in mind.

9. The two items read: 'How much do you trust your nearest superior?'; 'To what extent do you think that your nearest superior will keep his or her word when you agreed on something orally?' For the first item the response alternatives run from 0 ('Not at all') to 10 ('Completely'). For the last item the response alternatives run from 0 ('To no extent at all') to 10 ('Completely'). The zero order correlation between the two measures is 0.803 and Cronbach's alpha for the scale is consequently reassuringly high $(0.890)$.

10. All significance tests in the models are based on robust heteroskedasticity-corrected standard errors (Huber-White).

11. Given the initial asymmetrical power relationship between employers and employees (Offe and Wiesenthal 1980) we can interpret an increase in the scale measuring the employee's power over his or her superior as a decrease in power asymmetry. Thus, in the operational model an increase in the power scale should lead to higher levels of trust between the employee and his or her nearest superior.

12. It is worth noting here that our two measures of power are positively but not very strongly correlated $-r$ equals 0.22 . At a first glance the modest correlation might seem a bit problematic since we cannot assume that the two indicators tap the underlying construct in focus - power understood as the level of cost incurred if one unilaterally withdraws from a relationship - equally well. On the other hand, given this uncertainty it is reassuring that irrespective of the measure of power used we obtain the same pattern of effects.

13. Before concluding, a brief note on the robustness of the results is necessary. To check whether the results were unduly influenced by inclusion of any of the three items in the additive index on perceived fairness of institutions, we reestimated the models three times entering the variables separately. Furthermore, we also reestimated the models employing the two variables included in the trust index separately. Apart from small changes in the magnitudes of the estimated effects the results remained stable across all these model specifications. 


\section{REFERENCES}

Alesina, Alberto and La Ferrara, Eliana. 2002. 'Who Trusts Others?' Journal of Public Economics 85: 207-234.

Becker, Lawrence C. 1996. 'Trust as Noncognitive Security about Motives.' Ethics 107: 43-61.

Botero, Juan, Djankov, Simeon, La Porta, Rafael, Lopez-De-Silanes, Florencio and Shleifer, Andrei. 2004. 'The Regulation of Labor.' The Quarterly Journal of Economics 119: 1339-1382.

Coleman, James S. 1994. Foundations of Social Theory, Cambridge, MA: The Belknap Press of Harvard University Press.

Cook, Karen, Hardin, Russell, and Levi, Margaret. 2005. Cooperation Without Trust? New York: Russell Sage Foundation.

Crepaz, Markus M. L. 1992. 'Corporatism in Decline?' Comparative Political Studies 25: 139-168.

Delhey, Jan, and Newton, Kenneth. 2003. 'Who Trusts? The Origins of Social Trust in Seven Societies.' European Studies 5: 93-137.

DiMaggio, P. 1999. 'Review article on Trust and Governance.' Contemporary Sociology 28: 731-732.

Eichengreen, Barry and Iversen, Torben. 1999. 'Institutions and Economic Performance.' Oxford Review of Economic Policy 15: 121-138.

Elster, Jon. 1989. Nuts and Bolts for the Social Sciences. Cambridge University Press, Cambridge.

Farrell, Henry. 2004. 'Trust, Distrust, and Power.' In Russell Hardin (ed.), Distrust. New York: Russell Sage Foundation, pp. 85-105.

Foley, Michael W., and Edwards, Bob. 1999. 'Is it Time to Disinvest in Social Capital?' Journal of Public Policy 19: 199-231.

Glaeser, Edward L., David I. Laibson, José A. Scheinkman, and Christine L. Soutter. 2000. 'Measuring Trust.' Quarterly Journal of Economics 115: 811-846.

Golden, Miriam A. and Londregan, John B. 2006. 'Centralization of Bargaining and Wage Inequality.' American Journal of Political Science 50: 208-213.

Granovetter, Mark. 1985. 'Economic Action and Social Structures: The Problem of Embeddedness.' The American Journal of Sociology 91: 481-510.

Hall, Peter. 1986. Governing the Economy: The Politics of State Intervention in Britain and France. New York: Oxford University Press.

Hardin, Russell. 1993. 'The Street-Level Epistemology of Trust.' Politics and Society 21: 505-529.

Hardin, Russell. 1998. 'Trust in Government.' In Valerie Braithwaite and Margaret Levi (eds), Trust and Governance. New York: Russell Sage Foundation, pp. 9-27.

Hardin, Russell. 2002. Trust and Trustworthiness. New York: Russell Sage Foundation.

Hardin, Russell. 2004. 'Distrust: Manifestations and Management.' In Russell Hardin (ed.), Distrust. New York: Russell Sage Foundation, pp. 3-33.

Hibbs, Jr, Douglas A. 1976. 'Industrial Conflict in Advanced Industrial Societies.' The American Political Science Review 70 (4): 1033-1058.

Holmlund, Bertil, and Storrie, Donald. 2002. 'Temporary Work in Turbulent Times: The Swedish Experience.' The Economic Journal 112: F245-F269.

Iversen, Torben. 1998. 'Wage Bargaining, Central Bank Independence, and the Real Effects of Money.' International Organizations 52 (3): 469-504.

Knight, Jack. 1992. Institutions and Social Conflict. Cambridge: Cambridge University Press.

Knoke, David. 1990. Political Networks. The Structural Perspective. Cambridge: Cambridge University Press. 
Koelble, Thomas A. 1995. 'Review: The New Institutionalism in Political Science and Sociology.' Comparative Politics 27: 231-243.

Korpi, Walter. 1985. 'Power Resources Approach vs Action and Conflict: On Causal and Intentional Explanation in the Study of Power.' Sociological Theory 3: 31-45.

Kumlin, Staffan. 2004. The Personal and the Political. How Personal Welfare State Experiences Affect Political Trust and Ideology. New York: Palgrave Macmillan.

Kumlin, Staffan, and Rothstein, Bo. 2005. 'Making and Breaking Social Capital.' Comparative Political Studies 38: 339-365.

Letki, Natalia. 2006. 'Investigating the Roots of Civic Morality: Trust, Social Capital, and Institutional Performance.' Political Behavior 28: 305-325.

Levi, Margaret. 1991. 'Are There Limits to Rationality?' Archives Européennes de Sociologie 32: $130-141$.

Levi, Margaret. 1998. 'State of Trust.' In V. Braithwaite and M. A. Levi (eds), Trust and Governance. New York: Russell Sage Foundation, pp. 77-101.

Levi, Margaret, Moe, Matthew, and Buckley, Theresa. 2004. 'The Transaction Costs of Distrust.' In Hardin, Russell (ed.), Distrust. New York: Russell Sage Foundation, pp. 106-135.

Meyersson Milgrom, Eva, Petersen, Trond, and Snartland, Vemund. 2001. 'Equal Pay for Equal Work?' Scandinavian Journal of Economics 103: 559-583.

Miller, Alan S., and Tomoko Mitamura. 2003. 'Are Surveys on Trust Trustworthy?' Social Psychology Quarterly 66: 62-70.

North, Douglass. 1990. Institutions, Institutional Change, and Economic Performance. New York: Cambridge University Press.

Öberg, PerOla, and Svensson, Torsten. 2009. 'Does Power Drive Out Trust? Relations between Labour Market Actors in Sweden.' Political Studies, doi: 10.1111/j.1467-9248. 2008.00772.x.

Offe, Claus, and Wiesenthal, Helmut. 1980. 'Two Logics of Collective Action.' Political Power and Social Theory 1: 67-115.

Oskarsson, Sven. 2002. 'Class Struggle in the Wake of Globalisation. Union Organisation and Economic Integration,' pp. 193-238. In Lars Magnusson and Jan Ottosson (eds) Europe - One Labour Market? Brussels: Peter Lang.

Oskarsson, Sven. 2003. 'Institutional Explanations of Union Strength: An Assessment.' Politics and Society 4: 609-635.

Ostrom, Elinor. 1990. Governing the Commons: The Evolution of Institutions for Collective Action. New York: Cambridge University Press.

Ostrom, Elinor. 2000. 'Collective Action and the Evolution of Social Norms.' Journal of Economic Perspectives 14: 137-158.

Ouichi, William. 1980. 'Markets, Bureaucracies, and Clans.' Administrative Science Quarterly 25: 129-141.

Rawls, John. 1999 (1971). A Theory of Justice. (Revised edition). Cambridge, MA: The Belknap Press of Harvard University Press.

Rosenberg, Morris. 1956. 'Misanthropy and Political Ideology.' American Sociological Review 21: 690-695.

Rothstein, Bo. 2001. 'The Universal Welfare State as a Social Dilemma.' Rationality and Society 13: 213-233.

Rothstein, Bo. 2004. 'Social Trust and Honesty in Government.' In Kornai, János, Rothstein, Bo, and Rose-Ackerman, Susan (eds), Creating Social Trust in Post-Socialist Transition. New York: Palgrave Macmillan, pp. 60-82.

Rothstein, Bo, and Stolle, Dietlind. 2003. 'Social Capital in Scandinavia.' Scandinavian Political Studies 26: 1-26. 
Rothstein, Bo, and Uslaner, Eric. 2005. 'All for All. Equality, Corruption, and Social Trust.' World Politics 58: 41-72.

Rotter, Julian. 1971. 'Generalized Expectancies for Interpersonal Trust.' American Psychologist 26: 443-450.

Rotter, Julian. 1980. 'Interpersonal Trust, Trustworthiness, and Gullibility.' American Psychologist 35: 1-7.

Rydgren, Jens. 2004. 'Mechanisms of Exclusion: Ethnic Discrimination in the Swedish Labour Market.' Journal of Ethnic and Migration Studies 30: 697-716.

Shepsle, Kenneth A. 1989. 'Studying Institutions. Some lessons from the Rational Choice Approach.' Journal of Theoretical Politics 1: 131-147.

Sigeman, Tore. 2001. Arbetsrätten. En översikt över svensk rätt med europarätt. Stockholm: Norstedst Juridik.

Swedberg, Richard. 2003. Principles of Economic Sociology. Princeton: Princeton University Press.

Svensson, Torsten and Öberg, PerOla. 2005. 'How are Coordinated Market Economies Coordinated? Evidence from Sweden.' West European Politics, 28: 1075-1100.

Tyler, Tom R. 1998. 'Trust and Democratic Governance.' In V. Braithwaite and M. A. Levi (eds), Trust and Governance. New York: Russell Sage Foundation.

Ullmann-Margalit, Edna. 2004. 'Trust, Distrust, and In Between.' In Russell Hardin (ed.), Distrust. New York: Russell Sage Foundation, pp. 60-82.

Uslaner, Eric M. 2002. The Moral Foundations of Trust. Cambridge: Cambridge University Press.

Weber, Max. [1922] 1968. Economy and Society: An Outline of Interpretative Sociology. New York: Bedminster Press.

Williamson, Oliver. 1993. 'Calculativeness, Trust, and Economic Organization.' Journal of Law and Economics 36: 453-486.

Yamagishi, Toshio, and Midori Yamagishi. 1994. 'Trust and Commitment in the United States and Japan.' Motivation and Emotion 18: 129-166.

Zak, P. J. and Knack, S. 2001. 'Trust and Growth.' The Economic Journal 111: 295-321.

SVEN OSKARSSON is an assistant professor of Political Science at Uppsala University, Sweden. His current research interests concern power, trust, and loyalty in the Swedish labor market and political support among the affluent democracies. His recent publications include two articles in Politics and Society, book chapters and books.

ADDRESS: Department of Government, Uppsala University, Sweden, Box 514,75120 Uppsala, Sweden [email: sven.oskarsson@statsvet.uu.se]

TORSTEN SVENSSON is Professor of Political Science at Uppsala University, Sweden. His current interests concern power, trust, and loyalty in the Swedish labor market and within the labor market elite. His recent publications include articles in West European Politics, Governance, Scandinavian Political Studies, book chapters and books.

ADDRESS: Department of Government, Uppsala University, Sweden Box 514,75120 Uppsala, Sweden [email: torsten.svensson@ @statsvet.uu.se] 
PEROLA ÖBERG is associate professor in Political Science at Uppsala University, Sweden. His current interests concern social networks of trust and deliberation, and knowledge-based politics. His recent publications include articles in West European Politics, Governance, Scandinavian Political Studies, book chapters and books.

ADDRESS: Department of Government Uppsala University, Sweden Box 514,75120 Uppsala, Sweden [email: perola.oberg@ @statsvet.uu.se] 